\title{
EBV-induced miR-34a functions to stimulate transformed B cell growth
}

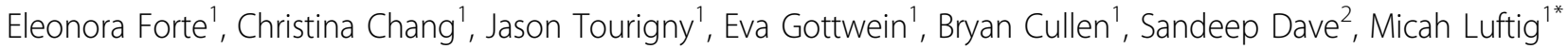 \\ From $12^{\text {th }}$ International Conference on Malignancies in AIDS and Other Acquired Immunodeficiencies \\ (ICMAOI) \\ Bethesda, MD, USA. 26-27 April, 2010
}

\section{Background}

Epstein-Barr virus (EBV) is a member of the $\gamma$-herpesvirus family estimated to infect $90 \%$ of the world's population. Despite the high prevalence of infection, EBV-associated malignancies are largely kept in check by a strong cytotoxic $\mathrm{T}$ cell immune response. However, EBV causes lymphoproliferative disease in immune-deficient individuals and plays a role in the pathogenesis of African Burkitt lymphoma, Hodgkin's disease, and nasopharyngeal carcinoma. In vitro, EBV infection of $B$ cells results in proliferation and outgrowth of indefinitely proliferating lymphoblastoid cell lines (LCLs). Thus, LCLs represent a viable model for the pathogenesis of EBV-associated malignancies.

microRNAs are small noncoding RNAs that posttranscriptionally regulate gene expression to control a variety of processes including development, cell cycle, and immunity. Their role in EBV transformation and lymphomas is currently not well understood.

\section{Results}

Using a miRNA microarray, we identified a number of cellular miRNAs that were over- or under-expressed comparing resting CD19+ B cells to EBV-infected, proliferating B cells and immortalized LCLs. In particular, we focused on miR-34a, whose expression was induced by EBV. This miRNA has been previously reported to be a pro-apoptotic target of p53 implicated in the response to DNA damage. Surprisingly, contrary to its regulation in other cell types, miR-34a was not found to be p53 responsive in LCLs. In order to understand the functional role of this miRNA in EBV transformation, we constructed a miRNA sponge. miR-34a knockdown

\footnotetext{
* Correspondence: micah.luftig@duke.edu

'Department of Molecular Genetics and Microbiology, Center of Virology,

Duke University School of Medicine, Durham, NC 27712, USA

Full list of author information is available at the end of the article
}

in LCLs showed that these cells depend on normal miR34a expression to proliferate and to aggregate.

\section{Conclusions}

miR-34a is important for efficient growth and survival of EBV-transformed cells, in contrast to its tumor suppressive role in carcinoma and sarcoma-derived cell lines.

\section{Acknowledgements}

This article has been published as part of Infectious Agents and Cancer Volume 5 Supplement 1, 2010: Proceedings of the $12^{\text {th }}$ International Conference on Malignancies in AIDS and Other Acquired

Immunodeficiencies (ICMAOI). The full contents of the supplement are available online at http://www.biomedcentral.com/1750-9378/5?issue=S1.

\section{Author details}

${ }^{1}$ Department of Molecular Genetics and Microbiology, Center of Virology, Duke University School of Medicine, Durham, NC 27712, USA. ²Duke Institute for Genome Sciences and Policy, Duke University, Durham, NC, USA.

Published: 11 October 2010

doi:10.1186/1750-9378-5-S1-A23

Cite this article as: Forte et al:: EBV-induced miR-34a functions to stimulate transformed B cell growth. Infectious Agents and Cancer 2010 5(Suppl 1):A23.

Submit your next manuscript to BioMed Central and take full advantage of:

- Convenient online submission

- Thorough peer review

- No space constraints or color figure charges

- Immediate publication on acceptance

- Inclusion in PubMed, CAS, Scopus and Google Scholar

- Research which is freely available for redistribution

Submit your manuscript at www.biomedcentral.com/submit
C Biomed Central 